\title{
Pengaruh Strategi Perubahan Nilai Car Terhadap Jangkauan Layanan Dan Risiko Pembiayaan Pada Lkm Koperasi Sejahtera Bangsaku
}

\author{
Ade Rachmawan ${ }^{1 *}$ Abdul Kohar ${ }^{\# 2}$ tb. Nur Ahmad Maulana ${ }^{\# 2}$ \\ 1) Mahasiswa program studi manajemen pascasarjana IPB \\ 2) Dosen program studi manajemen pascasarjana IPB
}

\begin{abstract}
The role of micro credit in poverty alleviation is very important. In Indonesia, performed by the Commercial Bank/ Islamic Banks of micro units, cooperative, rural bank/rural Islamic bank, and MFIs. Outreach microfinance services to the poor andmicro enterprisesin Indonesia is still very low. Perception of high risk for micro credit, especially loans to the poor/micro enterprises and lack of capital adequacy ratio (CAR) of rural bank/rural Islamic bank/ cooperative become obstacles for Financial institutions microlenders intermediation to the poor/micro enterprises or to financial institutions that will collaborate with MFIs in micro lending. Standardized Model approach is the basis for calculating CAR for Financial institutions microlendersin Indonesia. This method gives a risk weighting of $100 \%$ in the assessment of credit risk as a component of Risk Weighted Assets (RWA). CreditRisk+ method is a method of measuring credit risk models based on credit default approach that describes the amount and time limit information exposure and measurement of systematic credit risk of the borrower. By using this method, the credit risk is calculated as the ratio of the maximum estimate of bad debts to the credit balance. For MFIs with good performance of the NPL, then the value of RWA will be smaller, therefore the CAR is much bigger than the results of model calculations the standardized approach. With this result, outreach MFI services will increase as investors would not hesitate to cooperate in the delivery of microfinance to poor communities/micro enterprises.

Keywords :MFIs, outreach, RWA, CAR, CreditRisk+
\end{abstract}

\section{PENDAHULUAN}

Kredit mikro kepada masyarakat miskin dan usaha mikro sangat penting posisinya untuk pengentasan kemiskinan di Indonesia. Muhamamad Yunus, tokoh dan penemu Grameen Bank yang atas dedikasinya mendapat nobel perdamaian tahun 2006, mengatakan bahwa salah satu cara mengentasan masyarakat miskin adalah dengan memberikan kredit.

Jumlah penduduk miskin pada bulan September 2013 sebanyak 28,55 juta orang (BPS) atau $11,47 \%$ dari total penduduk Indonesia. Jumlah pengusaha mikrokecilpada tahun 2012 adalah 55.856.176(Kemenkop). Jumlah pengusaha mikroadalah 56.536 .560 pengusaha atau $98,79 \%$ dari total unit usaha.

Pelayanan kredit mikro di Indonesia dilakukan oleh bank dan non bank. Perbankan melalui BPR/BPRS dan berbagai unit mikro bank umum/bank umum syariah, seperti Danamon Simpan Pinjam, Unit Mikro Bank Mandiri dan Bank Unit Desa BRI. Lembaga non bank dikenal sebagai koperasi dan Lembaga Keuangan Mikro (LKM). Badan hukum LKM berbentuk Perseroan Terbatas atau koperasi. LKM ada juga yang berasal dari berbagai program dana bergulir dari pemerintah, seperti LPDB (Lembaga 
Pembiayaan Dana Bergulir), Program Nasional Pemberdayaan Masyarakat (PNPM), Lembaga Dana Kredit Pedesaan (LDKP) seperti Lembaga Perkreditan Kecamatan (LPK) di Jabar, Lumbung Putih, Badan kredit Desa (BKD) serta Lembaga Perkreditan Desa(LPD) di Bali. LKM non bank dari kalangan non pemerintah adalah koperasi simpan pinjam, koperasi kredit, Baitul Mal Wat Tamwil (BMT) dan berbagai kredit mikro dari LSM. Naskah akademik RUU LKM menyebutkan ada 637.838 LKM yang terbagi menjadi 31.363 LDKP,BKD dan LKM yang didirikan atas inisiatif masyarakat serta 606.475 LKM pendukung program pemerintah.(Bahrum A Siregar).

Berikut adalah data perbandingan kredit mikro dengan jumlah pengusaha mikro dan penduduk miskin di Indonesia.

Tabel 1. Jumlah Pengusaha Mikro dan Rekening Kredit Mikro di Indonesia (Jutaan)

\begin{tabular}{lcc}
\hline & 2013 \\
\hline Jumlah Pengusaha Mikro & 56,54 \\
Jumlah Kredit Mikro & 14,95 \\
Kredit Mikro disalurkan oleh Perbankan* & 10,14 & \\
Kredit Mikro disalurkan oleh KSP** & 3,05 & \\
Koperasi Syariah (BMT)** & 1,76 & \\
\hline
\end{tabular}

*) termasuk kredit kecil dan menengah

**) data BI tahun 2005

Tabel 1 menyatakan ada gap sekitar 41,59 juta pengusaha mikro yang belum mendapat layanan kredit mikro.Sementara berdasar Tabel 2 dibawah, jumlah masyarakat miskin yang belum dilayani kredit mikro sekitar 22,72 juta orang atau hanya $12,3 \%$ dari total penduduk miskin yang mendapat kredit mikro. Ini jelas tertinggaljauh dengan kredit mikro di kawasan Asia Pasifik.Microcredit Summit Campaignmenyebutkan pada tahun 2012 sebanyak 1.746 program pembiayaan mikro telah dilakukan dan pada tahun 2010 mencapai sekitar 169 juta klien untuk kawasan Asia-Pasific dengan tingkat jangkauan mencapai 68,8 persen. (I Gde Kajeng Baskara).

Tabel 2. Jumlah Penduduk miskin dan Rekening Kredit Mikro di Indonesia (Jutaan)

\begin{tabular}{lrr}
\hline & \multicolumn{2}{c}{2013} \\
\hline Jumlah Penduduk Miskin & 28,55 \\
Jumlah Kredit Mikro & 5,83 \\
Kredit Mikro disalurkan oleh LDKP** & 1,33 \\
Kredit Mikro disalurkan oleh Program PNPM & 3,17 \\
Kredit MiKro oleh PT Mitra Bisnis Keluarga & 0,33 \\
Kredit Mikro disalurkan oleh lainnya** & 1 & \\
\hline
\end{tabular}

**) data BI tahun 2005

Hambatan intermediasi lembaga keuangan kepada masyarakat miskin dan pengusaha mikro di Indonesia, khususnya oleh bank dan koperasi adalah persepsi masih besarnya 
risiko kredit mikro. Kredit atas kualitas angsuran dikelompokkan menjadi kredit lancar, kurang lancar, diragukan dan macet. Selanjutnya lembaga keuangan diwajibkan menyediakanpenyisihan penghapusan aktiva produktif (PPAP) yang dimasukkan sebagai biaya operasional. Besarnya PPAP adalah bobot risiko dikalikan nilai baki debet kredit setelah dikurangi jaminan. Karena pengusaha mikro dan masyarakat miskin sebagian besar tidak mempunyai jaminan/agunan, maka PPAP akan sangat besar untuk kredit mikro.

Pada sisi yang lain, manajemen risiko untuk kredit mikro akhir-akhir ini mengalami kemajuan yang signifikan. Metode Grameen Bank dengan pendekatan Tanggung Renteng, berhasil menekan Non Performing Loan(NPL) kredit mikro untuk masyarakat miskin sampai dibawah $0,5 \%$.

Faktor lain yang menghambat jangkauan pelayanan kredit mikro adalah ketentuan tentang Minimum Capital Requirement (MCR). Basel I memberi bobot risiko sebesar $100 \%$ untuk kredit sebagai salah satu komponen ATMR dalam penghitungan kecukupan modal minimum. Dalam Basel II, perhitungan risiko kredit menggunakan 2 pendekatan,yaitu standardized approach model dan IRB model (internal rating approach model).Salah satu metode dalam model IRB adalah Metode CreditRisk+. Penelitian yang dilakukan oleh Djatisasongko Tjahjowidjojo dalam tesis 'Aplikasi Metode Creditrisk+ dalam Penilaian Risiko Kredit untuk Segmen Kartu kredit pada pt Bank X' (2005)' menunjukkan bahwa metode ini cukup baik untuk digunakan mengukur risiko kartu kredit dan hasil perhitungan kebutuhan modal minimum menunjukkan bahwa penyediaan modal yang dibutuhkan dengan menggunakan metode ini hanya sebesar $0,51 \%$, jauh lebih rendah dibandingkan metode basic standardised untuk kredit ritel yang menuntut modal sebesar 6,29\% dari eksposur.

Berdasarkan latar belakang tersebut, rumusan masalah dalam penelitian ini adalah : 1) Apakah Metode CreditRisk+ bisa diterapkan pada Koperasi Sejahtera Bangsaku (KSB) untuk menentukan Minimum Capital Requirement?

2) Strategi apakah yang bisa diterapkan untuk meningkatkan ekspansi layanan pembiayaan mikro pada KSB?

Mengacu pada perumusan masalah seperti yang telah diuraikan di atas, maka tujuan penelitian ini adalah:

1) Menganalis penerapan CreditRisk+dalam mengukur minimum capital requirement pada KSB.

2) Merumuskan strategi bagi KSBuntuk meningkatkan layananpembiayaan mikro berdasarkan hasil penerapan metode CreditRisk+dalampengukuran MCR.

\section{METODE PENELITIAN}

Penelitian dilakukan di Koperasi Sejahtera Bangsaku (KSB). Koperasi yang memberikan kredit mikro kepada masyarakat miskin dengan model Grameen Bank. Data yang dikumpulkan dalam penelitian ini meliputi data primer dan sekunder.Data primer diperoleh melalui pencatatan, pengumpulan data dan wawancara langsung dengan pejabat berwenang yang terkait. Data sekunder diperoleh melalui data historis KSB, studi literatur, laporan penelitian dan publikasi elektronik. Jenis data sekunder yang digunakan adalah laporan keuangan dan laporan NPF pembiayaan mikro bulan Juli 2013 sampai dengan bulan Juni 2014 serta bahan-bahan penunjang yang terkait dengan penelitian.

Kualitas kredit pada BPR/BPRS dan koperasi digolongkan berdasarkan besarnya tunggakan angsuran. Penggolongannya menjadi 4 kakatgori, yaitu kredit lancar, kurang lancar, diragukan dan macet. Klasifikasi ini dikenal dengan istilah kolektibiltas. Pada 
LKM, pengolongan kolektibilitas menggunakan istilah yang berbeda yaitu PAR (Portofolio At Risk). Sebagian besar LKM di dunia menggolongkan PAR berdasarkan kelipatan setiap 30 hari tunggakan. Microsave menggolongkan PAR sebagai berikut:

1.PAR 0 hari : tunggakan 0

2.PAR 1- 30 hari : tunggakan 1 sd 30 hari

3.PAR 31-90 hari : : tunggakan 31 sd 90 hari

4.PAR 91-180 hari : tunggakan 31 sd 90 hari

5.PAR > 180 hari $\quad$ : tunggakan lebih180 hari

Metode CreditRisk+yang diperkenalkan oleh Credit Suisse First Boston (CSFB,1997) digunakan untuk menghitung risiko kredit pada KSB. CreditRisk+ bertujuan untuk menghitung distribusi kegagalan dari suatu kredit portofolio yang berdasarkan metodologi matematika. Dengan mengetahui distribusi kegagalan akan diketahui nilai risiko dari suatu portfolio kredit dan akhirnya dapat diketahui potensi risiko kredit jangka pendek.

CreditRisk+ digunakan untuk mencari peluang jumlah debitur yang default dalam suatu periode tertentu. Peluang jumlah debitur default ini dinyatakan dengan distribusi Poisson. Model ini menjadikan tingkat default sebagai peubah acak dan memasukan keragaman tingkat default untuk mengatasi ketidakpastian. Metode ini didasarkan pada pendekatan credit default model yang menggambarkan informasi jumlah dan batas waktu eksposure dan pengukuran risiko kredit sistematis dari debitur.

Metode CreditRisk memiliki kelebihan, yaitu relatif mudah untuk diimplementasikan dan kemudahan dalam ketersedian data.CreditRisk juga memfokuskan pada kondisi default yang dibutuhkan untuk mengestimasi potensi risiko. Data yang dibutuhkan hanya probability default, eksposuredan recovery rate (tingkat penerimaan kembali piutang yang sudah dihapusbukukan). CreditRisk+ memposisikan pada kondisi debitur tidak mampu membayar kewajiban yang dibutuhkan untuk mengestimasi potensi risiko.

Perumusan strategi peningkatan jangkauan layanan KSB didasarkan ke dalam kerangka pengambilan keputusan tiga (3) tahap yaitu tahap input, tahap pencocokan dan tahap keputusan (David, 2006). Pembuatan matriks EFE (External Factor Evaluation), digunakan untuk mengetahui faktor-faktor eksternal sebagai peluang dan ancaman bagi perusahaan. Matrik IFE (Internal Factor Evaluation) digunakan untuk mengetahui kekuatan dan kelemahan yang dimiliki perusahaan sebagai faktor internal sebagai tahap input.

Selanjutnya tahap pencocokan degan metode pembuatan matriks IE dan analisa SWOT. Gabungan matriks IFE dan EFE menghasilkan matriks IE, yaitu Sembilan macam sel yang memperlihatkan kombinasi total nilai terboboti dari matriks-matriksIFE dan EFE. Adatiga strategi utama, yakni :

1. Sel I, II dan IV : Strategi Tumbuh dan Membangun. Strategi yang cocok adalah Strategi Intensif atau strategi Integratif

2. Sel III, V dan VII disebut strategi Pertahankan dan Pelihara. Penetrasi pasar dan pengembangan produk merupakan dua strategiyang banyak dilakukan apabila perusahaan berada dalam sel ini.

3. Sel VI, VIII dan IX disebut strategi Panen dan Divestasi. 
Matriks SWOT merupakan matching tool yang penting untuk membantu para manajer mengembangkan empat tipe strategi :

1. Strategi SO (Strengths Opportunities): Strategi dengan mengoptimalkan kekuatan yang dimiliki untuk memanfaatkan berbagai peluang.

2. Strategi WO (Weaknesses Opportunities): Strategi dengan seoptimal mungkin meminimalisir kelemahan untuk memanfaatkan peluang.

3. Strategi ST (Strengths Threats): strategi yang digunakan perusahaan dengan mengoptimalkan kekuatanyang dimiliki untuk mengurangi ancaman.

4. Strategi WT (Weaknesses Threats): strategi yang digunakan perusahaan untuk mengurangi kelemahan dalam upaya menghindari ancaman.

Tahap pengambilan keputusan menggunakan Quantitative Strategic Planning Matrix (QSPM).QSPM merupakan suatu teknik yang secara objektif mengindikasikan alternatif strategi mana yang terbaik.QSPM memungkinkan evaluasi alternatif strategi berdasarkan faktor eksternal dan internal strategik yang telah diidentifikasi sebelumnya.Penggunaan QSPM membutuhkan penilaian intuitif yang baik.Secara konsep, QSPM menentukan daya tarik relatif dari berbagai strategi (David, 2006). Komponen penting dalam QSPM adalah bobot dari masing-masing faktor eksternal dan internal yang telah diidentifikasi sebelumnya serta attractiveness score (AS) yaitu nilai yang menunjukkan kemenarikan atau daya tarik relatif untuk masing-masing strategi yang dipilih. Pemilihan suatu strategi didasarkan pada nilai perkalian bobot dan AS atau disebut total attractiveness score (TAS). Nilai TAS yang paling tinggi menunjukkan alternatif strategi yang menjadi pilihan utama.

\section{HASIL DAN PEMBAHASAN}

KSB mulaiberoperasi tahun 2008. Sampai tahun 2013 sudah menyalurkan kredisenilai Rp5,35 milyar kepada lebih 3500 debitur. Pembiayaan menggunakan metode kelompok tanggung renteng yang dikenal dengan metode Grameen Bank.Debitur adalah perempuan usia 20 -50 tahun, pendapatan kotor Rp200.000 - Rp500.000 per pekan dan memiliki usaha home industri,buruh,pedagang dan petani.

Pelayanan transaksi pembiayaan dilakukan dalam pertemuan mingguan majelis yang terdiri dari 2-4 kelompok di sekitar rumah tinggal nasabah. Satu kelompok terdiri dari 5 orang.Pembiayaan tidak mensyaratkan adanya jaminan. Syarat mendapatkan pembiayaan adalah lulus Latihan Wajib Kelompok (LWK) selama 3 hari maksimum 1 jam per hari. Dalam LWK itulah tatacara tanggung renteng disosialisasikan. Tanggung renteng dilakukan di dalam kelompok dan antar kelompok dalam majelis yang sama. Tanggung renteng mewajibkan kepada anggota kelompok untuk menalangi anggota kelompok yang menunggak pembayaran angsuran. Bila kelompok belum seluruhnya bisa menalangi, maka pembayaran ditanggung oleh anggota kelompok lain dalam 1 majelis. Proses pembentukan kelompok dilakukan oleh dan antara mereka sendiri. Antara anggota saling menyeleksi untuk memastikan bahwa yang masuk kelompoknya adalah orang yang bisa dipercaya dan mampu membayar pembiayaan yang akan diterima. Di dalam pertemuan mingguan, dilakukan transaksi pembayaran angsuran, tabungan dan 
proses pengajuan pembiayaan sampai pencairan. Pertemuan dilakukan seminggu sekali selama 1 jam. Kedisiplinan melakukan pertemuan dilakukan secara ketat, karena ini merupakan bentuk monitoring pembiayaan. Selain ketepatan waktu pembayaran, kehadiran juga mempengaruhi persetujuan pembiayaan berikutnya. Proses persetujuan dilakukan dengan mempertimbangkan tingkat kehadiran anggota tersebut sekurangnya $80 \%$. Apabila kehadiran anggota kurang dari $80 \%$, maka yang bersangkutan akan dikenakan sanksi penundaan pembiayaan sampai tingkat kehadirannya terpenuhi. (Laporan RAT KSB 2014)

Jangka waktu pembiayaan 50 minggu, plafond pembiayaan minimal Rp200 ribu, paling besar Rp2,5 juta. Dengan demikian pembiayaan pada KSB seluruhnya adalah pembiayaan mikro. Angsuran setiap minggu paling kecil Rp6500, paling besar Rp64.000. Mayoritas anggota mendapat plafond diatas Rp500 ribu sampai dengan Rp1 juta.

Dalam pengukuran risiko kredit ini adalah CreditRisk+yang merupakan pendekatan DefaultModel.Data portofolio kredit dikelompokkan dalam kategori NonDefault (Performing Financing)yang terdiri dari eksposur dengan pinjaman lancar dan PAR 30 . Katagori pembiayaanDefault (Non Performing Financing) yaitu eksposur dengan $P A R$ 60, PAR 90, PAR 120 dan PAR> 120. Selama periode Juli 2013 - Juni 2014, NPF berkisar 0\% - 0,23\% , eksposur berkisar Rp 1,074 milyar - Rp2,304 milyar

\section{Perhitungan Risiko Pembiayaan dengan Metode CreditRisk+}

\section{Pengelompokan pembiayan dan eksposur dalam Band (banding)}

Plafond pembiayaan berkisar antaraRp200 ribu sampai dengan Rp2,5 juta, maka eksposur dikelompokkan dalam 10 unit band dengan unit of exposure masing-masing Rp250 ribu. Hasil penyusunan band dijelaskan sebagai berikut:

a. Band 1 : nilai eksposur Rp1 sampai dengan Rp250 ribu

b. Band 2 : nilai eksposur lebih besar dari Rp250 ribu s.d. Rp500 ribu

c. Band 3 : nilai eksposur lebih besar dari Rp500 ribu s.d. Rp750 ribu

d. Band 4: nilai eksposur lebih besar dari Rp750 ribu s.d. Rp1 juta

e. Band 5 : nilai eksposur lebih besar dari Rp1 juta s.d. Rp1,25 juta

f. Band 6: nilai eksposur lebih besar dari Rp1,25 juta s.d. Rp1,5 juta

g. Band 7: nilai eksposur lebih besar dari Rp1,5 juta s.d.Rp1,75 juta

h. Band 8 : nilai eksposur lebih besar dari Rp1,75 juta s.d. Rp2 juta

i. $\quad$ Band 9: nilai eksposur lebih besar dari Rp2 juta s.d. Rp2,5 juta

j. $\quad$ Band $10 \quad$ : nilai eksposur lebih besar dari Rp2,25 juta s.d. Rp2,5 juta

Berdasarkanband, saldo pembiayaan terkonsentrasi pada band 3 dan 4 dengan $57 \%$.Ini sesuai dengan penerima pembiayaan yaitu sebesar $65 \%$ terkonsentrasi pada plafond lebih dari Rp500 ribu sampai dengan Rp1 juta .Eksposur NPF pembiayaan mikro periode Juli 2013 sampai dengan Juni 2014 pada KSB, Band 1, 2 dan band 3 adalah band yang mengalami default. Sedangkan band yang lain tidak mengalami default. . Hal ini karena $40 \%$ alokasi pembiayaan adalah untuk modal kerja perdagangan sehingga tunggakan angsuran terjadi pada menjelang jatuh tempo pembiayaan. Pada awal pembiayaan modal yang berputar masih besar sehingga keuntungan yang diperoleh pun besar, sedangkan menjelang akhir pembiayaan, modal kerja mereka sudah berkurang karena terpakai konsumtif ataupun angsuran ke koperasi 
sehingga mempengaruhi kepada kemampuan mengangsur debitur.

\section{Penghitungan Default Rates}

Cara menghitung default rates $(D R)$ adalah dengan membagi nilai eksposur dengan nilai batas atas band nya.Di bawah ini adalah hasil perhitungan DR untuk bulan September 2013

Tabel 2. DR KSB September 2013

\begin{tabular}{|c|c|c|c|c|}
\hline & \multirow{2}{*}{ Band } & \multicolumn{2}{|c|}{ Saldo Pembiay Saldo NPF } & \multirow[t]{2}{*}{ DR } \\
\hline & & $\mathrm{Rp}$ & $\mathrm{Rp}$ & \\
\hline 1 & 250,000 & $100,444,500$ & $1,940,000$ & 7.76 \\
\hline 2 & 250,001 - & $130,003,360$ & 686,360 & 1.37 \\
\hline 3 & $500,001-750,000$ & $357,835,645$ & $\mathrm{O}$ & 0.00 \\
\hline 4 & $750,001-1,000,000$ & $280,214,000$ & $\mathrm{O}$ & 0.00 \\
\hline 5 & $1000,001-1,250,000$ & $80,098,000$ & $\mathrm{O}$ & 0.00 \\
\hline 6 & $1,250,001-1,500,000$ & $120,068,000$ & $\mathrm{O}$ & 0.00 \\
\hline 7 & 1,500,001 - 1,750,000 & $24,064,000$ & $\mathrm{O}$ & 0.00 \\
\hline 8 & 1,750,001 - 2,000,000 & $29,640,000$ & $\mathrm{O}$ & 0.00 \\
\hline 9 & $2,000,001-2,250,000$ & 0 & $\mathrm{O}$ & 0.00 \\
\hline 10 & $2,250,001-2,500,000$ & $\mathrm{O}$ & $\mathrm{O}$ & 0.00 \\
\hline
\end{tabular}

\section{Penghitungan Probability of Default}

Model Poisson digunakan untuk menghitung probability of default (PD) yangbertujuan menghitung distribusi kerugian masing-masing band. Rumus yang digunakan adalah sebagai berikut :

$$
\mathrm{e}^{-\kappa} \Lambda^{\mathrm{n}}
$$

$\operatorname{Prob}(\mathrm{n}$ default $)=$

$$
\mathrm{n} !
$$

$\Lambda=$ default rates

$\mathrm{e}=2,71828$

$\mathrm{n}$ = banyaknya kejadian default

Untuk perhitungan cumulative probability of default(cumPD)diperoleh dengan menjumlahkanprobability of default dari Prob (0)sampaiProb (n).

Hasil perhitungan PD dan cumPD disampaikan oleh tabel 4.

Tabel 4. PD dan CumPD September 2013 


\begin{tabular}{|c|c|c|c|c|c|c|c|c|c|c|c|c|c|c|c|c|c|c|c|c|}
\hline \multirow{2}{*}{$n$} & \multicolumn{2}{|c|}{ Band 1} & \multicolumn{2}{|c|}{ Band 2} & \multicolumn{2}{|c|}{ Band 3} & \multicolumn{2}{|c|}{ Band 4} & \multicolumn{2}{|c|}{ Band 5} & \multicolumn{2}{|c|}{ Band 6} & \multicolumn{2}{|c|}{ Band 7} & \multicolumn{2}{|c|}{ Band 8} & \multicolumn{2}{|c|}{ Band 9} & \multicolumn{2}{|c|}{ Band 10} \\
\hline & PD & cum PD & PD & cum PD & $\mathrm{PD}$ & cum PD & PD & cum PD & PD & cum PD & PD & cum PD & & cum PD & & cum PD & & cum PD & & cum PD \\
\hline 0 & 0.000426 & 0.000426 & 0.253417 & 0.253417 & 1 & 1 & 1 & 1 & 1 & 1 & 1 & 1 & & 1 & & 1 & & 1 & & 1 \\
\hline 1 & 0.003309 & 0.003736 & 0.347870 & 0.601287 & & & & & & & & & & & & & & & & \\
\hline 2 & 0.012840 & 0.016576 & 0.238764 & 0.840051 & & & & & & & & & & & & & & & & \\
\hline 3 & 0.033213 & 0.049789 & 0.109252 & 0.949303 & & & & & & & & & & & & & & & & \\
\hline 4 & 0.064433 & 0.114222 & 0.037493 & 0.986796 & & & & & & & & & & & & & & & & \\
\hline 5 & 0.100001 & 0.214223 & & & & & & & & & & & & & & & & & & \\
\hline 6 & 0.129334 & 0.343557 & & & & & & & & & & & & & & & & & & \\
\hline 7 & 0.143376 & 0.486933 & & & & & & & & & & & & & & & & & & \\
\hline 8 & 0.139075 & 0.626007 & & & & & & & & & & & & & & & & & & \\
\hline 9 & 0.119913 & 0.745921 & & & & & & & & & & & & & & & & & & \\
\hline 10 & 0.093053 & 0.838973 & & & & & & & & & & & & & & & & & & \\
\hline 11 & 0.065644 & 0.904618 & & & & & & & & & & & & & & & & & & \\
\hline 12 & 0.042450 & 0.947068 & & & & & & & & & & & & & & & & & & \\
\hline 13 & 0.025339 & 0.972407 & & & & & & & & & & & & & & & & & & \\
\hline 14 & 0.014045 & 0.986453 & & & & & & & & & & & & & & & & & & \\
\hline
\end{tabular}

Nilai PD tertinggi menunjukkan jumlah $\mathrm{n}$ kejadian tersebut adalah rata-rata default pada band tersebut. Untuk cumPD pada signifikansi tertentu, menunjukkan peluang terjadinya $\mathrm{n}$ kejadian tersebut adalah default maksimum pada band tersebut

Dari tabel 3 diatas, dapat dijelaskan bahwa untuk band 1, kejadian default tertinggi ada pada $\mathrm{n}=7$ dengan nilai 0,143376 . Artinya, akan ada kejadian 7 kali default untuk band 1 pada bulan September 2013 dengan nilai peluangnya 0,143376. Sedangkan dengan tingkat keyakinan 95\%, $\mathrm{n}$ terjadi pada $\mathrm{n}=12$ dengan nilai peluang cumPD 0,947068 dan peluangnya 0,04245. Artinya, kejadian default maksimum adalah 12 kali /orang dengan peluang kejadian itu di atas 12 adalah 0,04245 .

\section{Menghitung LGD, EL dan UL Sebagai Estimasi Kerugian Pembiayaan}

a)Loss Given Default (LGD) atau Severity of Loss.LGD digunakan untuk ukuran kerugian masing-masing band saat default.

$L G D=D R \mathrm{X}$ batas atas nilai band $\mathrm{X}(1-$ Recovery Rates $)$

Pada penelitian ini Recovery Rates $=0$.

Dengan demikian, contoh nilai LGDuntuk bulan September 2013 band 1 adalah Rp 1.940 .000

b) Expected Loss (EL) adalah rata-rata kerugian akibat default pada band dan Unexpected Loss (UL) adalah maksimum kerugian pada band yang diakibatkan default.UL disebut juga Value at Risk (VaR).

$$
\begin{aligned}
& \mathrm{ELA}_{\mathrm{A}}=\mathrm{LGD}_{\mathrm{A}} \times \mathrm{P}_{\mathrm{A}} \\
& \mathrm{UL}=\mathrm{n} \times \mathrm{L} \times \text { Real Loss }
\end{aligned}
$$

Untuk nilai $\mathrm{P}_{\mathrm{A}}$, saat $\mathrm{PD}$ tertinggi didapat $\mathrm{n}$ sebagai $\mathrm{n}$ kejadian default, Sedangkan $\mathrm{n}$ pada rumus UL adalah jumlah kejadian pada saat mendekati nilai persentile tertentu. Contoh perhitungan PD dan cum PD September 2013, nilai peluang tertinggi terjadi pada saat $n=7$, sedangkancumPD pada selang kepercayaan $95 \%$ diperoleh saat $n=12$. Nilai UL dan EL untuk band 1 bulan September 2013 adalah :

$$
\begin{aligned}
& \mathrm{EL}=7 \times \mathrm{Rp} 1.940 .000=\mathrm{Rp} 13.580 .000 \\
& \mathrm{UL}=12 \times \mathrm{Rp} 1.940 .000=\mathrm{Rp} 23.280 .000
\end{aligned}
$$


Rata-rata kerugian band 1 September 2013 adalah Rp 13,58 juta untuk 7 nasabah dengan tingkat peluang 0,143376. Nilai kerugian maksimum band 1 September 2013 adalah 12 nasabah dengan nilai kerugian Rp23.280.000 pada tingkat keyakinan 95\%.Selanjutnya besarnya EL dan UL untuk bulan September 2013 adalah penjumlahan masing-masing EL dan UL dari 10 band yang ada. Total EL September 2013 adalah Rp14.266.360, sedangkan total UL adalah Rp25.339.080.

Rata-rata rasio maksimum kerugian (UL) terhadap total pembiayaan periode juli 2013 sampai dengan Juni 2014 adalah 0,352\%. Sementara rata-rata default (EL) selama 12 bulan adalah $0,1763 \%$.

Tabel berikut adalah hasil perhitungan EL dan UL Juli 2013 - Juni 2014

Tabel 4. Expected Loss(EL) dan Unexpected Loss (UL) KSB

\begin{tabular}{lrr}
\hline \multicolumn{1}{c}{ Bulan } & Expected Loss & Unexpected Loss \\
\hline Juli 13 & 0 & $1,069,090$ \\
Agust 13 & 0 & $1,374,541$ \\
Sept 13 & $14,266,360$ & $25,339,080$ \\
Okt 13 & $6,650,000$ & $11,970,000$ \\
Nov 13 & $4,200,000$ & $8,400,001$ \\
Des 13 & 0 & 0 \\
Jan 14 & 0 & 760,000 \\
Feb 14 & 0 & 0 \\
Maret 14 & 0 & $1,140,000$ \\
April 14 & 0 & 0 \\
Mei 14 & 0 & 0 \\
Juni 14 & 0 & $1,326,916$ \\
\hline
\end{tabular}

Dari tabel 4 di atas, bulan September 2013 sampai dengan November 2013 adalah bulan yang beresiko untuk pembiayaan pada KSB. Ini adalah siklus tahunan, yaitu bulan setelah Lebaran dan menjelang Idul Qurban. Secara nominal bulan September 2013 mencatat UL dan EL terbesar. Tabel 4 di atas juga menjelaskan bahwa resiko pembiayaan padaKSB sangat rendah. Untuk bulan September 2013 sebagai bulan yang sangat beresiko, nilai EL adalah Rp 14.266.360 dan nilai UL adalah Rp 25.339.080.

5. Menghitung Economic Capital

Economic Capital adalah Besarnya modal yang diperlukan untuk dapatmenutup kerugian ketika kerugian mencapai level unexpected loss.Expected Loss adalah kerugian yang dapat diperkirakan terjadinya.Kerugian akibat kejadian expected loss dicover dengan pencadangan modal yang diperoleh daripengenaan provisi kepada debitur dan dari penyisihan penghapusan aktiva produktif (PPAP).Economic Capital diperoleh dari selisih UL dengan EL. Karena KSB belum mencadangkan PPAP dan tidak mengenakan provisi, maka economic capital sama dengan UL. Tabel berikut adalah perhitungan Rasio UL terhadap saldo pembiayaan selama periode pengamatan Tabel 5. Rasio UL terhadap Saldo pembiayaan Juli 2013 - Juni 2014 


\begin{tabular}{|c|c|c|c|}
\hline Bulan & UL (Rp) & Saldo Pembiayaan (Rp) & \% UL/Saldo pembiayaar \\
\hline Juli 13 & $1,069,090$ & $1,074,227,753.96$ & 0.100 \\
\hline Agust 13 & $1,374,541$ & $1,066,590,857.60$ & 0.129 \\
\hline Sept 13 & $25,339,080$ & $1,122,367,505.60$ & 2.258 \\
\hline Okt 13 & $11,970,000$ & $1,242,958,565.60$ & 0.963 \\
\hline Nov 13 & $8,400,001$ & $1,356,876,813.60$ & 0.619 \\
\hline Des 13 & 0 & $1,536,474,861.49$ & 0.000 \\
\hline Jan 14 & 760,000 & $1,709,366,251.04$ & 0.044 \\
\hline Feb 14 & 0 & $1,815,726,719.14$ & 0.000 \\
\hline Maret 14 & $1,140,000$ & $2,121,132,015.04$ & 0.054 \\
\hline April 14 & 0 & $2,294,760,355.04$ & 0.000 \\
\hline Mei 14 & 0 & $2,353,201,179.04$ & 0.000 \\
\hline Juni 14 & $1,326,916$ & $2,304,588,524.54$ & 0.058 \\
\hline
\end{tabular}

Bulan September 2013, rasio UL terhadap saldo pembiayaan adalah yang terbesar yaitu $2.26 \%$. Rata-rata selama periode pengamatan adalah $0.352 \%$ dari saldo pembiayaan. Dengan mengacu kepada ketentuan modal minimum $8 \%$, maka KSB harus menyediakan modal minimum untuk mengcover kerugian akibat kredit macet sebesar 0,352\% X 8\% =0,0282\% dari saldo pembiayaan atau sebesar Rp 648.959

\section{Uji Validitas Model}

\section{1) Back Testing}

Pengujian model secara Back Testing dengan cara membandingkan nilai actual loss dengan perkiraan maksimum kerugian.Perkiraan maksimum kerugian diperoleh dari nilai UL , actual loss adalah nilai NPF.

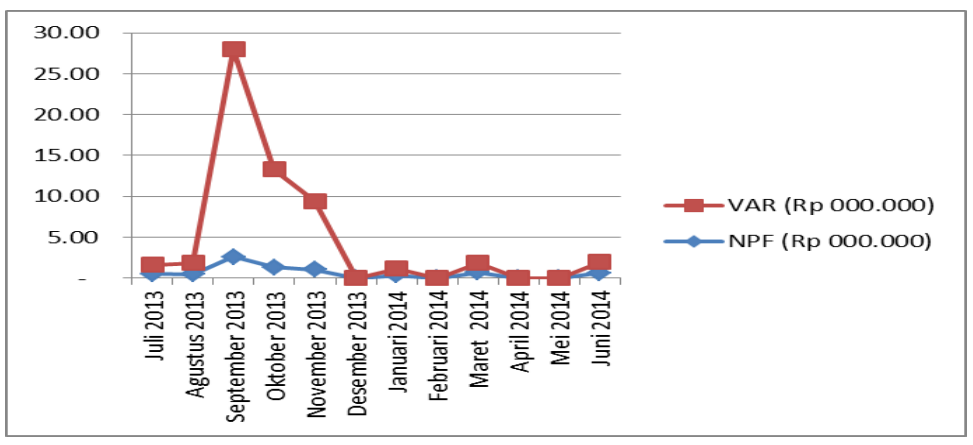

Gambar 1.Grafik Actual Loss (NPF) dan Perkiraan Maksimum Kerugian (VaR)

Gambar 1 memperlihatkan nilai VaR selalu diatas actual loss. Ini berarti bahwa model bisa memproyeksikan secara akurat kerugian yang terjadi akibat default.

Metode Back Testing yang lain adalah dengan membandingan antara default rates dengan volatilities-nya. Pada selang kepercayaan 95\%, dari tabel distribusi normal diperoleh nilai 1,65 sebagaibatas toleransi terjadinya kesalahan. Hasil perhitungan menunjukkan bulan September 2013 band 1, bulan Oktober 2013 dan November 2013 nilai $D R$ lebih besar dari nilai 1,65 $\sigma$. Ini menunjukkan bahwa 3 band dari 120 band atau 2,5\% model tidak akurat memproyeksikan kerugian.

\section{2) Likelihood RatioTest}


Likelihood Ratio(LR) Test adalah metode uji validasi model dengan menghitung jumlah banyaknya actual loss yang melebihi nilai VaR selama periode obeservasi.

Rumus LR test sebagai berikut :

$$
L R=-2 \log \left[\left(1-p^{-}\right)^{N}\left(p^{-}\right)^{N}\right]+2 \log \left\{\left[1-\left(\frac{N}{T}\right)\right]^{T-N}\left(\frac{N}{T}\right)^{N}\right\}
$$

Gambar 1, memperlihatkan bahwa actual loss (NPF) selama periode observasi selalu dibawah VaRnya. Dengan demikian jumlah kesalahan estimasi adalah 0 dari 12 pengamatan. Dengan memasukkan $\mathrm{p}=5 \%, N=0$ dan $T=12$ ke dalam rumus, hasil LR adalah 0,5346. Nilai sebaran Chi- Square pada derajat bebas 1 dengan selang kepercayaan $95 \%$ adalah 3,841. Nilai LR test $(0,5346)$ dibawah nilai Chi-Squarenya $(3,841)$, sehingga model creditRisk+ ini valid dan bisaditerima untuk perhitungan resiko pembiayaan pada KSB.

\section{Perhitungan Hasil MetodeCreditRisk+ Untuk Menghitung CAR}

Suatu LKM dikatagorikan sehat bila memiliki nilai CAR lebih dari 8\%. PBI no 8/22/PBI/2006 dan SE no 82006 Dpbs serta Permeneg Koperasi dan UKM no 20/per/M.KUKM/XI/2008 menghitung resiko pembiayaan dengan bobot 100\% sebagai bagian dari Aktiva . Perhitungan ATMR untuk KSB menghasilkan nilai 2,537,297,774sehingga dengan modal inti Rp 468,708,120 nilaiCAR 18,47\%.

Penghitungan ATMR dengan menggunakan hasil metode CreditRisk+, bobotrisiko pembiayaan KSB dihitung sebagai hasil dari perbandingan nilai UL terhadap total saldo pembiayaan. Rata-rata rasio UL terhadap saldo pembiayaan adalah $0,352 \%$, sehingga nilai ATMR koperasi Sejahtera Bangsaku menjadiRp240,831,100 dan CAR menjadi $194,62 \%$.

Implikasi dari hasil ini, dengan mengacu pada CAR8\% sebagai minimum capital requirement, maka KSB bisa menerima pembiayaan modal kerja untuk melakukan ekspansi pembiayaan hingga Rp1,497 trilyun atau meningkat 650 kali lipat dari posisi Juni 2014. Peningkatan jangkauan layanan pembiayaan menjadi 1.982 .500 orang dari 3050 debitur pada posisi juni 2014. Ini jauh lebih besar dibanding peningkatan pelayanan 2 kali lipat saja bila bobot resiko pembiayaan dihitung 100\% atau menjadi 6100 debitur .

Pendekatan lain untuk menghitung potensi kemampuan ekspansi adalah dengan menghitung rasio maksimum kerugian terhadap pembiayaan dibandingkan dengan modal yang dimiliki. Modal Koperasi Sejahtera Bangsaku bulan Juni 2014 adalah Rp451,1 juta. Rata-rata rasio Unexpected Loan (estimasi kredit macet maksimum ) terhadap pembiayaan adalah $0,352 \%$. Dengan rasio ini, maka Rp451,1 juta bila diasumsikan untuk mengcover kerugian maksimum pembiayaan, maka total pembiayaan yang bisa diberikan adalah Rp 128,2 milyar dengan jangkauan 128.000 debitur

\section{Analisis Internal dan Eksternal Koperasi Sejahtera Bangsaku}


Berdasarkan analisa kondisi lingkungan internal dan eksternalKSB, maka kekuatanKSB adalah 1)Metode Pembiayaan dengan model Grameen Bank sudah teruji dan dikuasai,Dengan parameter debitur dan pembiayaan tumbuh secara pesat, PAR rendah dan rasio keuangan diatas rataan industry.2) Dukungan dari pendiri, ini ditunjukkan dengan 63\% modal kerja berasal dari jaringan Peramu di Bogor. 3) Loyalitas SDM tinggi, dibuktikan dari berdiri sampai tahun 2014, hanya 1 orang SDM yang keluar.

Kelemahan yang dimiliki KSB adalah1) Pengembangan SDM belum terencana.2)Terbatasnya modal kerja untuk pembiayaan. Dana yang berhasil dihimpun dari masyarakat masih sedikit, karena Tasikmalaya sebagai daerah untuk lending bukan menghimpun dana masyarakat. BPS Tasikmalaya mencatat bahwa untuk tahun 2012 dana pihak III perbankan sebesar 5,993 trilyun rupiah di kabupaten tasikmalaya dan 342 milyar rupiah di kota Tasiklmaya. Sementara kredit yang diserap tahun 2012 sebesar 9,303 trilyun rupiah di kabupaten dan 547 Milyar rupiah di kota Tasilmalaya. 3) Ekuiti sulit bertambah.

Peluang yang ada adalah 1) Segmen pasar pembiayaan mikro kepada masyarakat miskin masih tinggi untuk daerah Tasikmalaya dan Ciamis.Tahun 2010, penduduk Tasikmalaya yang miskin sebanyak 376.045 orang. Sementara yang dilayani oleh koperasi sampai dengan maret 20143201 debitur. Wilayah operasi KSB baru beroperasi di 4 kecamatan dari total 39 kecamatan di Tasikmalaya dan 2 kecamatan di Ciamis dari total 36 kecamatan2) Bank umum syariah sebagai sumber pendanaan 3) Jumlah LKM lain yang beroperasi di Tasikmalaya masih sedikit. Di daerah kabupaten Tasikmalaya, ada 354 koperasi sementara ciamis 892 koperasi. Tetapi belum ada koperasi simpan pinjam yang melakukan kredit dengan model Grameen Bank4) Kultur masyarakat dalam wirausaha tinggi.

Ancaman yang dihadapi adalah :1) Persaingan dengan Lembaga lain, yaitu BTPN dan MBK. MBK adalah LKM model Grameen Bank terbesar di Indonesia. Sejak tahun 2008 sudah beroperasi di Tasikmalaya. Sementara BTPN juga mengembangkan model grameen di nasional. Sejak tahun 2012 juga memberikan pembiayaan di Tasikmalaya. Ancaman untuk KSB adalah kedua lembaga itu mempunyai dana yang kuat.2) Bencana alam (longsor dan gempa).Daerah Tasikmalaya dan Ciamis termasuk dataran tinggi. Ancaman longsor dan gempa kerap terjadi. Tahun 2012, terjadi 20 kali longsor di Ciamis (BPS Ciamis). Sementara itu 73 desa di Tasikmalaya, tergolong tinggi rawan longsor. (BPS Tasikmalaya)

\section{Analisis Matriks Internal Factor Evaluation (IFE)KSB}

KSB memiliki kekuatan utama metode gramen yang sudah teruji dan dikuasai dengan baik oleh koperasi dengan skor 0,691.Kelemahan utama modal kerja yang terbatas untuk melakukan ekspansi pembiayaan dengan skor 0,322.Total skor 2,711 menunjukkan posisi koperasi kuat secara internal dalam pengertian kekuatan bisa digunakan untuk menutup kelemahan yang ada pada koperasi.

\section{Analisis Matriks External Factor Evaluation (EFE) KSB}

Peluang utama koperasi adalah segmen pasar pembiayaan mikro yang sangat besar dan kultur masyarakat sebagai wirausahawan yang tinggidengan masing-masing skor 0,879. Ancaman utama adalah persaingan dengan BTPN dan NBK (skor 0,211). Ini direspon 
dengan penguatan pelayanan pada model GrameenBank yang dilakukan KSB.Total skor 3,129 menunjukkan posisi koperasi sangat bagus merespon peluang dan ancaman yang berasal dari lingkungan.

\section{Analisis Matriks IE KSB}

Matriks IE (internal eksternal) disusun dari total skor matriks IFE dan EFE. Ini akan menunjukkan perusahaan terletak pada kuadran tertentu yang mencerminkan posisi perusahaan. Matriks IFE bagi KSB menghasilkan skor 2,711, sementara matriks EFE menghasilkan skore 3,129. Skor ini menempatkan KSB pada posisi kuadran II yaitu posisi tumbuh dan kembangkan. Posisi ini menjelaskan bahwa KSB harus mempunyai kebijakan ekspansi karena peluang yang sangat besar bisa dijadikan keuntungan dengan kekuatan yang dimiliki. Hal ini juga karena ancaman yang ada masih belum besar. Adapun kelemahan internal, bisa ditutupi oleh kekuatan yang dimiliki. Posisi KSB dalam matriks IE disajikan dalam matriks IE dibawah ini.

\begin{tabular}{|c|c|c|c|c|}
\hline & & \multicolumn{3}{|c|}{ Skor Total IFE } \\
\hline & & $\begin{array}{c}\text { Kuat } \\
(3,0-4,0)\end{array}$ & $\begin{array}{c}\text { Rataan } \\
(2,0-2,99)\end{array}$ & $\begin{array}{c}\text { Lemah } \\
(1,0-1,99)\end{array}$ \\
\hline \multirow{3}{*}{ 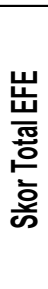 } & $\begin{array}{c}\text { Kuat } \\
(3,0-4,0)\end{array}$ & $\begin{array}{c}\text { I } \\
\text { Tumbuh dan } \\
\text { Kembangkan }\end{array}$ & $\begin{array}{l}\text { II } \\
\text { Tumbuh dan } \\
\text { Kembangk. }\end{array}$ & $\begin{array}{c}\text { III } \\
\text { Jaga dan } \\
\text { Pertahankan }\end{array}$ \\
\hline & $\begin{array}{c}\text { Rataan } \\
(2,0-2,99)\end{array}$ & $\begin{array}{c}\text { IV } \\
\text { Tumbuh dan } \\
\text { Kembangkan }\end{array}$ & $\begin{array}{c}\text { V } \\
\text { Jaga dan } \\
\text { Pertahankan }\end{array}$ & $\begin{array}{c}\text { VI } \\
\text { Tuai atau } \\
\text { Divestasi }\end{array}$ \\
\hline & $\begin{array}{c}\text { Rendah } \\
(1,0-1,99)\end{array}$ & $\begin{array}{c}\text { VII } \\
\text { Jaga dan } \\
\text { Pertahankan }\end{array}$ & $\begin{array}{c}\text { VIII } \\
\text { Tuai atau } \\
\text { Divestasi }\end{array}$ & $\begin{array}{l}\text { IX } \\
\text { Tuai atau } \\
\text { Divestasi }\end{array}$ \\
\hline
\end{tabular}

Gambar2.Matriks IE KSB Juni 2014

\section{Analisis Matriks SWOT}

Alternatif strategi kunci untuk mengoptimalkan kekuatan dan memanfaatkan peluanag serta mengurangi kelemahan dan mengatasi ancaman digambarkan oleh matriks SWOT berikut ini.

Matriks SWOT digambarkan dalam gambar 3 dibawah ini .

\begin{tabular}{|c|c|c|}
\hline EFE & $\begin{array}{c}\text { Strength } \\
\text { Metode Grameen sudah teruji dan } \\
\text { dikuasai }\end{array}$ & $\begin{array}{c}\text { Weakness } \\
\text { modal kerja penyaluran } \\
\text { pembiayaan terbatas }\end{array}$ \\
\hline $\begin{array}{c}\text { Opportunity } \\
\text { Pasar pembiayaan } \\
\text { Mikro di tasikmalaya } \\
\text { masih besar } \\
\text { Kultur wirausaha } \\
\text { masyarakat tinggi }\end{array}$ & $\begin{array}{c}\text { Ekspansi pembiayaan mikro } \\
\text { dengan model gramen yang } \\
\text { mengedepankan nilai-nilai logis, } \\
\text { transparans dan saling } \\
\text { menguntungkan }\end{array}$ & $\begin{array}{l}\text { Pengembangan produk model } \\
\text { garmeen }(+) \text { yaitu model grameen } \\
\text { dengan pendampingan usaha }\end{array}$ \\
\hline $\begin{array}{c}\text { Treath } \\
\text { Persaingan dengan } \\
\text { MBK dan BTPN }\end{array}$ & $\begin{array}{c}\text { Penerapan SOP Metode Grameen } \\
\text { secara ketat, bermutu dan } \\
\text { mengedepankan kepuasan } \\
\text { pelanggan }\end{array}$ & $\begin{array}{l}\text { Perencanaan kebutuhan } \\
\text { pembiayaan pada debitur secara } \\
\text { tepat jumlah dan tepat waktu }\end{array}$ \\
\hline
\end{tabular}

Gambar 3.Strategi Utama Koperasi Sejahtera Bangsaku 2014 


\section{Analisa Quantitative Strategic Planning Model}

Hasil analisa IFE, EFE dan analisa IE dijadikan input dalam analisa matriks QSPM untuk memilih strategi mana yang akan diterapkan. Hasil analisa matrik QSPM disajikan dalam tabel 5 dibawah ini.

Tabel 5. Matriks QSPM KSB Juni 2014

\begin{tabular}{|c|l|c|}
\hline Urutan & \multicolumn{1}{|c|}{ strategi } & $\begin{array}{c}\text { nilai TAS (Total } \\
\text { Attractiveness } \\
\text { Score) }\end{array}$ \\
\hline 1 & $\begin{array}{l}\text { Penerapan Standar Metode Gramen secara ketat , } \\
\text { bermutu dan mengedepankan kepuasaan pelanggan } \\
\text { Perencanaan Pembiayaan pada debitur secara tepat } \\
\text { waktu dan tepat jumlah }\end{array}$ & 1.9959 \\
\hline 2 & $\begin{array}{l}\text { Ekspansi Pembiayaan Mikro dengan mengedepankan } \\
\text { nilai-nilai logis, transparan dan saling menguntungkan } \\
\text { Pengembangan produk model grameen yang } \\
\text { menekankan pada kebutuhan pengembangan usaha }\end{array}$ & 1.9959 \\
\hline 4 & 1.4934 \\
\hline
\end{tabular}

Dengan demikian, strategi penerapan standar model grameen secara ketat, bermutu dan mengedepankan kepuasan pelanggan dan strategi Perencanaan pembiayaan pada debitur secara tepat waktu dan tepat jumlah srtategi adalah strategi yang menjadi prioritas pada KSB.

\section{SIMPULAN}

Dari pembahasan mengenaiPengaruhStrategiPerubahan Nilai CAR Terhadap Jangkauan Layanan dan Risiko Pembiayaan pada LKM Koperasi Sejahtera Bangsaku , diperoleh kesimpulan sebagai berikut :

1) Metode CreditRisk+ dapat secara akurat digunakan untuk menghitung risiko pembiayaan mikro pada koperasi Sejahtera bangsakau berdasarkanUji Backtesting dan Likelihood Ratio test. Uji backtesting selama periode observasinilaiUnexpected Loss sebagainilai estimasi kerugian maksimum selalu diatas actual loss/NPF. Nilai Likelihood Ratio test pada selang kepercayaan 95\% adalah 0,5346 dibawah nilai Chi-Squarenya sebesar 3,841.

2) Perhitungan CAR sebagai Minimum Capital requirement dengan metode CreditRisk+menghasilkan nilai CAR194,62\% . Perhitungan CAR dengan metode standardized approach modelmenghasilkannilai CAR 18,47\%.

3) Terdapat 4 (empat) strategi untuk melaksanakan pengelolaan pembiayaan mikro pada Koperasi Sejahtera Bangsaku, yaitu :

1. Strategi penerapan standar model Grameen Banksecara ketat, bermutu dan mengedepankan kepuasan pelanggan.

2. Strategi perencanaan pembiayaan pada debitur secara tepat waktu dan tepat jumlah.

3. Strategi ekspansi pembiayaan mikro dengan mengedepankan nilai-nilai logis, transparan dan saling menguntungkan.

4. Pengembangan produk model Gramen Bank yang menekankan pada pengembangan usaha.

\section{DAFTAR PUSTAKA}

Baskara, I G K.2013.Lembaga Keuangan Mikro di Indonesia.(jurnal) Jurnal Buletin Study Ekonomi. Fakultas Ekonomi dan bisnis universitas Udayana,Bali. 
Bank Indonesia.2006. Peraturan Bank Indonesia Nomor: 8/24/pbi/2006Tentang Penilaian kualitas aktiva Bagi bank perkreditan rakyat berdasarkan Prinsip syariah. Jakarta

Bank Indonesia.2006. SE no 82006 Dpbs perihal Kewajiban Penyediaan modal Minimum bagi Bank Perkreditan Rakyat Berdasarkan Prinsip Syariah. Jakarta

Kemenegkop dan UMKM. 2008. Peraturan Mentri Negara Koperasi dan UKM no 20/per/M.KUKM/XI/2008 Tentang Pedoman Penilaian Kesehatan Koperasi Simpan Pinjam dan Unit Simpan Pinjam Koperasi. Jakarta.

BIS.2013.Abrief History of Basel Committee.Bank For International Settlement.

BPS. 2014. Profil Kemiskinan di Indonesia September 2013. Berita Resmi Statistik no 06/01/th. XVII. Biro Pusat Statistik, Jakarta.

BPS Ciamis. 2014.Kabupaten Ciamis dalam Angka tahun 2013. Ciamis

BPS Tasikmalaya. 2014.Kabupaten Tasikmalaya dalam Angka tahun 2013.Tasikmalaya.

CSFB.Credit Suisse First Boston, (1997). CreditRisk+, a Credit Risk Management Framework

Corry, D. 2004. Penerapan Model CreditRisk+ dalam Penilaian Risiko Kredit Mikro Sektor Usaha di Bank BRI [Tesis]. Jakarta (ID): Program Studi Magister Manajemen, Fakultas Ekonomi Universitas Indonesia.

David, F. 2009. Manajemen Strategi (Terjemahan). Salemba Empat, Jakarta.

Gema PKM Indonesia.2003.Kemiskinan dan Keuangan Mikro.Sekretariat Jendral Gema PKM Indonesia, Jakarta.

MBK.2014. Mitra Binis Keluarga Ventura. Tersedia pada http://www.mbkventura.com/id/

Microsave,.2008.Basic Financial Management and Ratio Analysis for MFIs Toolkit.Tersedia pada www.microsave.net

OJK.2013.Statistik Perbankan Indonesia volume 12 no.1.Data Perkreditan.Otoritas Jasa Keuangan, Jakarta.

.2013.Perkembangan Kredit UMKM dan MKM Desember 2013_BD. Otoritas Jasa Keuangan, Jakarta.

PNPM Mandiri Perkotaan. 2014. Progres Kinerja Pinjaman Dana Bergulir Nasional, status data Desember 2013. Tersedia pada http://www.p2kp.org/laporan/files /microfinance /RLF_Nas_des13_Update290114.pdf

Siregar, A Bahrum.Fasilitasi peran lembaga keuangan mikro $(\mathrm{km})$ dalam rangka memperkuat perekonomian daerah. Departemen Dalam Negeri RI.

Tjahjowidjojo, D. 2005. Aplikasi Metode CreditRisk+ dalam Penilaian Risiko Kredit untuk Segmen Kartu Kredit pada PT Bank X [Tesis]. Jakarta (ID): Program Studi Magister Manajemen, Fakultas Ekonomi Universitas Indonesia 